\title{
CEO rhetorical strategies and firms' internationalization: a communication perspective
}

\author{
Qiuyue Shao
}

School of Economics and Management, Tongji University, Shanghai, China https://orcid.org/0000-0003-1699-2852

\section{Shouming Chen}

School of Economics and Management, Tongji University, Shanghai, China https://orcid.org/0000-0003-2050-7565

\section{Peien Chen}

Eli Broad College of Business, Michigan State University, East Lansing, MI 48824, USA

https://orcid.org/0000-0003-1034-8214

\begin{abstract}
Based on the upper echelons theory, previous literature has suggested that CEO's personal characteristics influence firms' internationalization. However, most research investigates the static traits such as age, education, overseas background, etc. Since CEO's communication skills exert influence on the firm as well, communication may also be of significance in the process of firm internationalization. We proposed that three CEO rhetoric strategies affect firm internationalization by persuading employees to recognize the international purpose and contribute to it jointly. Using the data of CEO rhetorical strategies and the level of internationalization of 118 Chinese listed firms, we tested the influence of CEO rhetoric strategy on firms' internationalization. The results show that two CEO rhetoric strategies - Ethos and Pathos - affect firm internationalization positively. The findings reveal that proper strategy of CEO communication is important for the execution of firms' internationalization.
\end{abstract}

Keywords

rhetoric, internationalization, CEO, upper echelons theory, communication

\section{Introduction}

The internationalization of firms means that the firms conduct business activities across national borders (Tihanyi, L., Ellstrand, A. E., Daily, C. M., \& Dalton, D. R., 2000), which belongs to the strategy of firm regional diversification. International operations can reduce the volatility of business risks and returns (Kim, W. C., Hwang, P., \& Burgers, W. P., 1993; Tallman \& Li, 1996), bring organizations a competitive advantage (Dunning, 1993), and bring more opportunities for firm growth (Wolf, 1977). Because the strategic decision and execution of the firm are mainly affected by CEOs (Haynes \& Hillman, 2010), extant research from upper echelons theory on corporate internationalization strategies mostly involves the relationship between the CEOs' personal traits and corporate internationalization strategy, and rarely studies how CEOs can effectively persuade employees to participate in the process of corporate internationalization.

In order to fill this gap, this research looks innovatively at how CEOs influence the implementation of corporate internationalization strategies, that is, how to use rhetoric to persuade internal and external stakeholders to seek internationalization jointly and take part in 
international operations. This article will focus on the internal communication of firms, that is, whether the CEOs' rhetorical strategies can motivate the internationalization by popularizing the management vision to all levels of the firm, and eventually encourage stakeholders to work together towards a firm's internationalization goal.

The purpose of this study is to demonstrate that CEOs using rhetorical strategies aimed at persuading employees to participate in international business activities could effectively accelerate the internationalization of firms. While the relevance and rationale of CEO communication and positioning is prevalent in academic and professional literature (Bendisch, F., Larsen, G., \& Trueman, M., 2013; Fanelli \& Misangyi, 2006; Men, 2012; Sohn, Y. Y., Weaver Lariscy, R., \& Tinkham, S. F., 2009; Wæraas, 2010), CEOs are expected to use narrative strategies and influential rhetoric (Grafström \& Falkman Lena, 2017). They use strategic communication and public relations as a professional practice to manage communication activities and relationships between organizations and their stakeholders (Hallahan, K., Holtzhausen, D., van Ruler, B., Verčič, D., \& Sriramesh, K., 2007; Verčič \& Grunig, 2000). Rhetorical strategies have gradually entered the field of management and become part of leadership practice and research. Different rhetorical strategies will affect employees' work participation to varying degrees (Liu, C., Chen, S., \& Shao, Q., 2019), and then affect the international operation results of firms (Braet, 1992). In order to investigate the influence of rhetorical strategies by CEOs, we have proposed three hypotheses about the three rhetorical techniques, which come from Aristotle's classification of rhetorical methods: ethos, pathos, and logos. Through text analysis methods applied to annual reports of listed manufacturing firms, we will ascertain which of these three rhetorical techniques were used. We set up a multiple regression model to test whether the use of CEO rhetoric really affects the improvement of the inter-nationalization of the firm.

\section{Theory and hypotheses}

Regarding the internationalization of firms, Wind, Douglas and Perlmutter, (1973) consider it to be a process in which a specific attitude or tendency is closely related to the gradual growth of the implementation of internationalization. There are also some scholars who define the internationalization of firms as an increasingly coherent and orderly process of internationalization participation (Bilkey \& Tesar, 1977). Some research incorporates the awareness of internationalization of firms into the scope of the definition, pointing out that internationalization refers to the process by which firms gradually attach importance to the influence of future internationalization activities (Beamish, P. W., Morrison, A. J., \& Rosenzweig, P. M., 1997). In addition, dynamics and time elements cannot be ignored in the definition of internationalization. Internationalization describes a time-dependent process and can therefore be summarized as an evolving law (Jones \& Coviello, 2005).

The motivation of firm internationalization is also the starting point of theoretical research on internationalization. Regarding why firms should be internationalized, Dunning's theory of corporate mergers proposes an "eclectic paradigm" for international production, that is, when a firm has three advantages at the same time: ownership advantages, internalization advantages, and internationalization advantages, direct foreign investment behavior will occur. Hymer (1976) believes that the monopoly advantages of home country firms over similar firms in the host country are the motivation for firms to invest overseas. The product cycle theory proposed by Vernon (1966) believes that the place of production depends on different stages of the product life cycle. Aliber (1970) pointed out that the motivation for firms to engage in overseas investment lies in the differences in capitalization rates in different countries and focuses on analyzing the impact of macroeconomic variables, such as currency, on overseas investment. The above theories are based on the methods of multinational firms in developed countries and have become mainstream theories of international research. Wells (1968) is representative in terms of the research on the results of firm internationalization in developing countries. He proposed that protecting export markets is the most important motivation for manufacturing firms in developing countries to invest abroad.

Internationalization strategy is considered to be a vital strategy for a firm (Hitt, M. A., Hoskisson, R. E., \& Ireland, R. D., 1994). It drives information needs and distributes information for competitive analysis, resource allocation, and strategic management (Zahra, S. A., Neubaum, D. O., \& ElHagrassey, G. M., 2002). Regarding the influencing factors of the internationalization strategy, the existing research has been conducted around the following four dimensions: firm level, 
industry level, transaction-specific level and institutional background. Among them, one of the focuses of firm-level research is the impact of corporate management. Upper Echelons theory (Hambrick \& Mason, 1984) holds that strategic choice is a complex decision in that it is the result of the interaction of multiple behavioral factors and reflects the characteristics of decision makers' cognitive tendencies, values, and knowledge reserves. Only in recent decades has the discussion of the effects of top management team composition been extended to the context of MNCs and firm internationalization (Herrmann \& Datta, 2005). At present, a large number of empirical studies on corporate internationalization have shown that top managers play an extremely important role in corporate internationalization strategies (Beckman \& Burton, 2008; Herrmann \& Datta, 2005; Hitt et al., 1994; McKiernan, 1992). Most of the research on the level of internationalization in China focuses on factors of the CEO such as salary, age, tenure and education level (Jaw \& Lin, 2009), confirming that the personal characteristics of CEOs affect the strategic decision-making of internationalization.

Further, Bartlett and Ghoshal (2002) have proposed that the most successful firms are those who are able to develop a common understanding of a clear and consistent corporate vision. The understanding and acceptance of vision can function as a global glue (Den Hartog \& Verburg, 1997) to result in incremental appreciation and commitment from individual managers. In fact, the quality of strategy made by top management teams will be strengthened if they pay attention to the interaction process, such as communication with middle managers, first-line managers and staff, improving their enthusiasm (Liu, X. H., GE, Y. H., \& Wang, Q., 2014). Although it is accepted that communication of vision and leader rhetoric are important, there is lack of explanation about why leader rhetoric is related to speech charisma in terms of producing strong emotional and motivational effects on followers (Shamir, B., Arthur, M. B., \& House, R. J., 1994). This article attempts to classify the rhetorical strategies taken advantage of by CEOs and study the impact of $\mathrm{CEO}$ rhetoric on the internationalization of firms.

To specify the definition and usage of the word 'rhetoric', we refer to Aristotle's work on rhetoric. In ancient Greece, Aristotle defined rhetoric as the ability to find viable ways of persuasion in each case (Cope, 1877), emphasizing rhetoric as an ability to present arguments. In addition, Aristotle categorized the rhetorical strategies into three types: Ethos, Pathos, and Logos. Ethos is showing the audience character, affecting the audience with wisdom and virtues, making them believe in the speaker and accept his point of view. Pathos is realized through the persuader's control over the emotions of the audience. Logos convinces the audience through rational or logical reasoning.

On the one hand, rhetoric, as a symbolic method rooted in the essential function of language, essentially induces people's cooperative behavior. It concentrates on bringing a persuasive and influential side to the discourse of leaders. On the other hand, CEOs play an important part in creating and dispersing organizational values and visions to organization members and the external environment. Their speeches within and outside the firm are important to motivate others and gain support for their vision (Den Hartog \& Verburg, 1997). On the basis of the perspectives above, we wonder whether a CEO's rhetorical strategy affects the degree of internationalization. What is the mechanism of rhetoric's effect on the internationalization?

\subsection{Credibility appeals: ethos strategy}

The rhetorical definition of ethos refers to an image the speaker projects to the audience (Kallendorf \& Kallendorf, 1985). In line with Aristotle, a speaker communicates a credible ethos to the audience when he shows the audience his intelligence, upright character and goodwill (Cooper, 1935). Kennedy (2007) pointed out that ethos, as a way of persuasion, refers to the trustworthy qualities that the speaker deliberately shows in their speech. Based on the above research, Halloran (1982) concluded our understanding of ethos, including authority, good character and reputation. Therefore, although Aristotle's ethos strategy has a different interpretation in following rhetorical research, it still does not deviate from the three basic elements proposed by Aristotle: wisdom, virtue, and goodwill.

Empirical investigations suggests that ethos creates trust, which contributes to credibility and higher performance among the audience. Ethos strategy is in action when the message conveyed by a speaker functions as the medium through which his personality activates the dominant response of value (Rosenthal, 1966). In other words, speakers want their audience to have a positive impression of them in order to motivate the audience or readers to trust what they say, agree with them and, ultimately, cooperate with them (Kallendorf \& 
Kallendorf, 1985). During this process, intelligence and credibility count. Burtt and Falkenberg (1941) found that expert opinions have more significant influence than the majority views. It has been discovered that, when the speaker holds a higher status than others, his cloze test scores will be somewhat higher (Harms, 1961). It means that the impact of ethos strategy, which shows intelligence, wisdom and upright character, is meaningful for credibility creation. Further, ethos is essential for elevating performance. Previous research found that rhetoric of personal suggestion is capable of affecting performance in kinds of perceptual and psychomotor assignments (Aveling \& Hargreaves, 1921).

Moreover, it is important to note that a leader's personal ethos promotes organizational vision (Yoeli \& Berkovich, 2010) that pushes the organization to have a greater chance of success in the long term (Larwood, L., Falbe, C. M., Kriger, M. P., \& Miesing, P., 1995). A leader's ethos mirrors his values and beliefs, which are a key to understanding his personal vision (Chance, 1992). The description of a leader's vision is regarded as the springboard to create change in organizations (Awamleh \& Gardner, 1999). It functions as a motivation for effort towards the future described in the vision (Berson, Y., Shamir, B., Avolio, B. J., \& Popper, M., 2001). In particular, empirical research demonstrated that a CEO' $\mathrm{s}$ vision and endeavor strongly matters for international path and expansion (Gentile - Lüdecke, S., Halaszovich, T., \& Lundan, S., 2019). Since scholars assume that a leader's vision is conveyed and strengthened by his ethos (Caza, A., Barker, B. A., \& Cameron, K. S., 2004), we suggest, employees should be persuaded by CEO ethos strategy to be convinced of internationalization and joint efforts will be devoted to achieving a firm's goal of international growth. Therefore, we propose that:

H1: CEO ethos strategy is positively related to firm internationalization.

\subsection{Affective appeals: pathos strategy}

Pathos is a mood of a speech which puts the audience into a certain habit of mind (Braet, 1992), from which we derive both the English words 'passion' and 'passive' (Konstan, 2006). For arousing these emotions, Aristotle posited three sides of rules for us: the condition of audience's emotions, the persons about whom one feels emotions and the motive (Gerson, 1999).

Emotions can undoubtedly influence stakeholders' decision-making (Schwarz, 2000). Existing research demonstrated that moral emotions are essential to human decisions (Callahan, 1988) for which Waddell (1990) called for greater acceptance of the legitimacy of emotion. In political psychology, it has been supported by dual-process models that automatic process is one of the paths for individuals to form an opinion (Lieberman, 2007), and the automatic process constitutes an emotional foundation for decision-making (Haidt, 2007).

Bagozzi, Gopinath, and Nyer (1999) not only argue that emotional valence affects decisionmaking, but also, in a step further, that the more intense the anticipated emotions, the more people were encouraged to achieve the success and avoid potential failure. Leaders who appropriately employ emotions to communicate, or who testify better awareness of their own emotions and those of others, perform at a higher level (Goleman, 1998). Similarly, leadership scholars also posited that leaders' expression of their emotions is one of the mainly productivity-relevant methods to affect performance (Humphrey, 2002). When followers observe and experience the emotional expression of a leader, they may be emotionally influenced through emotional contagion (Hatfield, E., Rapson, R. L., \& Le, Y.-C. L.,- 2011). It has been shown that the potential mechanism through which CEO's emotional display may influence employees' action is through the attributions and expectations implicated by CEO's expressed emotion (Wang \& Seibert, 2015). In the study into rhetoric of international business leaders, Hartog (1997) also emphasized the emotional effects on followers that CEO speeches should have.

In sum, pathos strategy, which aims to create emotions and passions among stakeholders, is vital for firm internationalization performance. Therefore, we propose that:

$\mathrm{H} 2$ : CEO pathos strategy is positively related to firm internationalization.

\subsection{Rational appeals: logos strategy}

According to Aristotle, logical proof is identified as a method in speech that proves or seems to prove a speaker's point. Specifically, it requires skillful application of syllogisms (Braet, 1992). Logos, which appeals to logic, received the greatest focus of attention among three types of rhetorical justification (Brown, A. D., Ainsworth, S., \& Grant, D., 2012). It stands for the clarity, integrity and utility put forward through verbal argumentation and logical reasoning (Holt \& 
Macpherson, 2010). In essence, the process of persuading others is based on the original facts of logical reasoning or quoting examples to achieve a common position between the speaker and the listener (common ground) (Stalnaker, 2002).

Empirical investigations concentrating on logos appeals have demonstrated that the argumentations and structure make them persuasive (Brown et al., 2012). Some scholars' research into communication strategies compared three types of rhetorical strategies and argued that Chinese CEO communications are based more on rational appeals to be understood in international markets (Huang \& Rose, 2018). Holt and Macpherson (2010) conducted case studies among entrepreneurs and found that the manager turning to logos, including using formal records of continuous improvement, meant he exhibited an authoritative nature of the activity the firm was engaged in, helping the firm win new customers.

Logos appeals are correlated with logical calculations of means and ends and thus evoke legitimacy for transnational firms. It has been found that firm risk is positively related to internationalization (Bartov, E., Bodnar, G. M., \& Kaul, A., 1996) and that firms intending to conduct overseas business are faced with the challenge of gaining legitimacy (Bangara, A., Freeman, S., \& Schroder, W., 2012). Suchman (1995) elaborates three kinds of legitimacy: cognitive legitimacy (based on taken-for-grantedness), pragmatic legitimacy (exchange evaluation of benefits) and moral legitimacy (normative and without consideration of practical benefits). Among three kinds of legitimacy, cognitive and pragmatic legitimacy are considered the dominant forms of legitimacy taken advantage of by firms, especially in the increasingly international society (Scherer \& Palazzo, 2007). Previous research held the view that logos appeals are highly correlated with the cognitive and pragmatic legitimacy. Suchman (1995) posited that the rhetoric of logos is competent for creating cognitive legitimacy among audiences through plausible explanations. Further, Sandy Edward Green (2004) emphasized that pragmatic legitimacy is conferred by catering to the audiences' self-interests in terms of logos appeals.

For international firms exposed to the liability of foreignness during internationalization, they are at disadvantage of competing with local firms (Bangara et al., 2012), which necessitates the requirement to build legitimacy as a method to gain needed resources to survive and develop
(Zimmerman \& Zeitz, 2002). Besides, strategic communication has been considered as playing an important role, in the way of strengthening recognition and confidence for corporate actions, so that legitimacy can be fostered to ensure the licenses to operate overseas (Keller-Bacher \& Zerfass, 2019). In sum, the rhetoric of logos is competent and necessary to develop corporate legitimacy for firm internationalization. Therefore,

H3: CEO Logos and the degree of corporate internationalization are positively related.

\section{Method}

\subsection{Data and samples}

The samples selected in this study were all manufacturing firms listed on the Shanghai Stock Exchange and Shenzhen Stock Exchange in China from 2015 to 2016, and the samples were selected as follows: (1) delete samples with trading status of ST and PT; (2) delete samples with zero overseas sales revenue or overseas subsidiaries; (3) delete samples with asset-liability ratios greater than 1 ; (4) delete samples which went through a CEO change at that time; (5) delete samples with missing data. The reasons for sample selection are as follows: first, the unified selection of manufacturing firms ensures the comparability and validity of data and ensures that sample firms are in a similar external environment, and that CEO rhetoric strategies and other variables are effectively measured. Secondly, according to the industry classification index released by the China securities regulatory commission, manufacturing firms account for about $60 \%$ of China's listed firms, indicating their importance in China's economic development and strong value to research. Finally, the reason why we choose a sample of 2015-2016 is that since 2015 China's economic growth has flattened, and manufacturing firms have been faced with internal differentiation. According to Dunning's investment development cycle theory, as domestic demand tends toward saturation and labor costs increase, domestic firms begin to tend towards an asset transfer strategy, such as engaging in foreign investment. In this context, the establishment of internationalization strategy is the result of the internal and external environments, and the promotion of the internationalization process has become one of the trends of some Chinese manufacturing firms. Therefore, 2015-2016 is a key period for firms to make decisions and implement measures reflecting their response to external pressure. In addition, 
considering the lagging effect of CEO rhetoric strategy on firm internationalization, the indicator of firm internationalization lags behind CEO rhetoric strategy by one period. Finally, the independent variable and control variable we measured is period $t$, and the dependent variable we measured is period $t+1$, that is, the year of the independent variable and control variable we selected is 2015 , and the year of the dependent variable we selected is 2016 .

The data sources used in this study are the Juchao Website, Wind database and China Stock Market \& Accounting Research Database (CSMAR). The CEO's rhetorical strategies come from the text analysis of the annual report of the firm published by Juchao, a professional website providing complete annual reports. The internationalization degree of the firm is based on relevant data such as overseas income published by Wind database. The control variables are divided into two levels of indicators, namely, the firm level and the CEO level, both from the CSMAR database. After stripping out the missing businesses, there were 118 observations.

\subsection{Measurement}

\subsubsection{Dependent variable}

We take the change of firm internationalization index as the dependent variable, that is, the proportion of the firm's overseas income in the total revenue of the firm (FSTS) as the indicator to measure the degree of firm internationalization, and take the ratio change from 2015 to 2016 as the dependent variable of this study. Considering the different internationalization foundation of different manufacturing firms, it is difficult to detect the influence of CEO rhetorical strategies on internationalization process by taking the absolute value of internationalization index as the dependent variable. In addition, based on the gradual and continuous characteristics of firm internationalization, the indicators should reflect the progress of firm internationalization to a certain extent. Therefore, we choose the change of ratio as the dependent variable to reflect the effect of the independent variable more precisely.

\subsubsection{Independent variables}

The CEO's rhetorical strategies are obtained by analysing annual reports related to internationalization. Text analysis, or content analysis, is defined as a systematic, replicable method that compresses text phrases into content categories based on specific coding rules. Since previous studies did not establish a direct rule for analysing CEO rhetoric strategies, it is difficult to obtain CEO rhetorical strategies through keyword retrieval or artificial intelligence. Therefore, this study adopts the artificial text analysis method to code selected samples one by one. In light of the fact that most corporate executives refuse to fill in questionnaires, the information about corporate executives obtained from the questionnaire survey method is often greatly biased. Therefore, the data obtained from the text analysis of the publicly disclosed archived information of firms is easy to obtain and reliable.

By analysing public texts written or approved by the CEO, we can obtain comprehensive information about the use of CEO rhetorical strategy more directly. In social activities, individuals' language styles and diction reflect their psychological activities and cognitive modes. The annual report, which to some extent reflects the CEO's style of speeches and contains a large amount of information, is a reasonable way to obtain the knowledge and cognition of CEOs. This paper collects and analyses the rhetorical strategy of annual reports in order to know the vision of a CEO to promote firm internationalization, the strength of their vision, and further analyses the influence of such rhetorical strategy. The following are three rhetorical techniques for analysing the text of the annual report:

\section{- Ethos.}

Ethos is used to demonstrate the firm's international capabilities. The application of the ethos technique in the annual report of the firm is mainly manifested in the results achieved by the firm's internationalization. By showing wisdom, virtues and professionalism, a firm's existing strength in expanding overseas business is verified so that spiritual incentives are produced to encourage employees to further expand their overseas business and enhance their internationalization. In addition, ethos rhetoric can directly improve corporate credibility and reliability, and prove to investors the strength of the CEO's international operations, enhancing the prestige of the CEO's further corporate internationalization. Once the ethos text appears in the firm's annual report, it is coded as 1 , otherwise it is 0 .

\section{- 2.2.1.2. Pathos.}

Pathos is used to present the inter-national aspirations of the firm. One of the environmental factors influencing the inter-nationalization of 
firms is the desire for inter-nationalization, which refers to the inter-nationalized business orientation of firms and their managers, that is, to engage in business operations with the orientation to broad whole markets in the world. Pathos technique is expressed in texts such as quoting proverbs and poems, using ancient classics, substituting true feelings, passionately stating the firm's internationalization desire, and demonstrating the firm's determination to expand overseas. Pathos technique reflects the diversified writing skills of the firm's annual report, fully mobilizes the reader's emotions, immerses them in empathy with the $\mathrm{CEO}$, and make them have a deeper sense of the CEO's business goals. Once it appears in the text of the firm annual report, it is coded as 1 , otherwise it is 0 .

\section{- 2.2.1.3. Logos.}

Logos is used to express reasons for internationalization. Internationalization needs, including the requirements for the internationalization of firms by changes in the external environment (the "thrust" and "gravity" of the environment for the firm's internationalization) and the necessity of the firm's own requirements for internationalization (by the firm's products, research and development, etc.). The main application of logos is to explain the cause and effect of the establishment of the firm's internationalization strategy in the annual report of the firm, and to state reasonably why the firm should be internationalized and how to achieve internationalization. When the CEO uses logic to persuade rationality, high-frequency phrases such as: causality (because, so), adversative (though, but), conjunction (in addition, further), objectively and clearly state the essence of the firm's internationalization strategy and offer explanation of necessity and significance of implementation. Once the relevant statement appears in the firm's annual report, it is coded as 1 , otherwise it is 0 .

\subsubsection{Control variables}

In order to exclude the potential influence of other variables on the dependent variable, based on existing research, this paper introduces two levels of control variables. First, the firm level controls the asset-liability ratio, the nature of ownership, the industry and the size of the firm; second, the CEO level controls the duality, age, tenure, and education.

\section{- $\quad$ Firm-level control variables}

The following factors that may affect the degree of internationalization have been set as control variables: (1) Asset-liability ratio - the proportion of total corporate liabilities in total assets in 2015 is used. (2) Nature of ownership - the state-owned firm code is 1 and the rest are 0. (3) Industry according to the secondary industry standards for manufacturing industry issued by the CSRC, it is divided into 13 industries with a total of 12 dummy variables. (4) Firm scale - the natural logarithm of the firm's total assets in 2015 is used.

\section{- CEO-level control variables}

Based on upper echelon theories, CEOs' cognitive tendencies, values, and knowledge reserves can influence a firm's strategic choices. Therefore, the following CEO personal characteristics introduce control variables: (1) Whether the CEO holds both positions. If the CEO is concurrently chairman, the value is set to 1 , otherwise it is set to 0. (2) CEO's age. The CEO's age in 2015 is taken as the unit. (3) CEO's term. The number of years a CEO has held the position at listed firms in 2015 is adopted. (4) Education level. The value of technical secondary school and below is 1 ; the value of junior college is 2; the value of master's degree is 4 ; the value of doctoral students is 5; others (academic qualifications published in other forms, such as honorary doctorates, correspondence, etc.) is set to 6 , and MBA / EMBA is set to 7 .

\section{Results}

\subsection{Descriptive statistics and correlation analysis}

Table 1 shows descriptive statistical results for all variables. Among a total of 118 observations, the increase in the internationalization index among firms varies greatly, with a maximum increase of $97 \%$ and a minimum decrease of $30 \%$. The average age of the CEO is 49.178 years old, the average education level is a bachelor's degree and a master's degree, and the average term is 4.6 years. At the time, $0.8 \%$ of the CEOs were concurrently directors of the firm.

\subsection{Regression results}

$\mathrm{H} 1$ proposes that the use of CEO ethos rhetoric will positively affect the internationalization process of firms. Because the coefficient of the independent variable ethos in Model 5 of Table 2 is positive $(\beta=0.06, p<0.001)$, we can see that the use of ethos rhetorical strategies has a significant positive impact. Therefore, compared with firms whose CEOs do not use ethos rhetorical strategies, 
firms that use ethos rhetorical strategies will achieve greater progress in the firm's internationalization indicators.

$\mathrm{H} 2$ proposes that the CEO's use of pathos rhetoric will positively affect the internationalization process of firms. According to the results of multiple regression analysis, the coefficient of the independent variable pathos is positive, but $\beta=0.005$, and the $p$ value is 0.9 , which indicates that the use of pathos rhetoric has no significant effect on the internationalization process of the firm, so $\mathrm{H} 2$ cannot be accepted.

Table 1 Descriptive statistics and correlation analysis

\begin{tabular}{|c|c|c|c|c|c|c|c|}
\hline Variable & Mean & SD. & 1 & 2 & 3 & 4 & 5 \\
\hline 1. Increase & .008 & .116 & 1.000 & & & & \\
\hline 2. Ethos & .686 & .466 & $.299^{*}$ & 1.000 & & & \\
\hline 3. Pathos & .22 & .416 & .057 & .089 & 1.000 & & \\
\hline 4. Logos & .170 & 0.13 & $.220^{*}$ & $.227^{*}$ & .089 & 1.000 & \\
\hline 5. Lev & .431 & .193 & $-.224^{*}$ & -.014 & .050 & .050 & 1.000 \\
\hline 6. Sta & .144 & .353 & -.069 & -.054 & -.043 & -.043 & .106 \\
\hline 7. Dua & .008 & .092 & -.011 & -.012 & .174 & .174 & .128 \\
\hline 8. Age & 49.178 & 7.884 & -.123 & -.062 & -.078 & -.080 & .097 \\
\hline 9. Edu & 3.39 & 1.497 & -.067 & -.034 & .067 & .067 & .097 \\
\hline 10. Ten & 4.634 & 3.633 & .007 & -.090 & .135 & .135 & .040 \\
\hline 11. Ind & 7.847 & 3.085 & .164 & .092 & .073 & .073 & .073 \\
\hline 12. Scale & 22.875 & 1.322 & -.150 & .074 & .246 & .246 & .608 \\
\hline Variable & 6 & 7 & 8 & 9 & 10 & 11 & 12 \\
\hline 6. Sta & 1.000 & & & - & - & & \\
\hline 7. Dua & -.038 & 1.000 & & & & & \\
\hline 8. Age & -.068 & .104 & 1.000 & 2 & & & \\
\hline 9. Edu & -.107 & -.024 & -.117 & 1.000 & & & \\
\hline 10. Ten & .066 & .118 & -.134 & -.032 & 1.000 & & \\
\hline 11. Ind & .075 & .095 & -.134 & .056 & -.084 & 1.000 & \\
\hline 12. Scale & .087 & .180 & .079 & .066 & .125 & $.123^{*}$ & $1.000^{*}$ \\
\hline
\end{tabular}

Source: the authors' calculation in Stata 13.1 based on secondary data

Table 2 Estimates for the multiple regression analysis results

\begin{tabular}{|c|c|c|c|c|c|}
\hline Variables & Model1 & Model2 & Model3 & Model4 & Model5 \\
\hline Lev & $\begin{array}{l}-0.114 \\
(0.069)\end{array}$ & $\begin{array}{l}-0.098 \\
(0.067)\end{array}$ & $\begin{array}{l}-0.112 \\
(0.070)\end{array}$ & $\begin{array}{l}-0.092 \\
(0.068)\end{array}$ & $\begin{array}{l}-0.082 \\
(0.067)\end{array}$ \\
\hline Sta & $\begin{array}{l}-0.024 \\
(0.031) \\
\end{array}$ & $\begin{array}{l}-0.014 \\
(0.030) \\
\end{array}$ & $\begin{array}{l}-0.023 \\
(0.031)\end{array}$ & $\begin{array}{l}-0.019 \\
(0.030)\end{array}$ & $\begin{array}{l}-0.011 \\
(0.029) \\
\end{array}$ \\
\hline Dua & $\begin{array}{l}0.015 \\
(0.118)\end{array}$ & $\begin{array}{l}0.002 \\
(0.114)\end{array}$ & $\begin{array}{l}0.017 \\
(0.119)\end{array}$ & $\begin{array}{l}-0.034 \\
(0.117)\end{array}$ & $\begin{array}{l}-0.036 \\
(0.114)\end{array}$ \\
\hline Age & $\begin{array}{l}-0.001 \\
(0.001) \\
\end{array}$ & $\begin{array}{l}-0.001 \\
(0.001)\end{array}$ & $\begin{array}{l}-0.001 \\
(0.001) \\
\end{array}$ & $\begin{array}{l}-0.001 \\
(0.001)\end{array}$ & $\begin{array}{l}-0.001 \\
(0.001) \\
\end{array}$ \\
\hline Edu & $\begin{array}{l}-0.006 \\
(0.007)\end{array}$ & $\begin{array}{l}-0.005 \\
(0.007)\end{array}$ & $\begin{array}{l}-0.005 \\
(0.007)\end{array}$ & $\begin{array}{l}-0.007 \\
(0.007)\end{array}$ & $\begin{array}{l}-0.006 \\
(0.007)\end{array}$ \\
\hline Ten & $\begin{array}{l}0.001 \\
(0.003) \\
\end{array}$ & $\begin{array}{l}0.001 \\
(0.003)\end{array}$ & $\begin{array}{l}0.001 \\
(0.003) \\
\end{array}$ & $\begin{array}{l}0.000 \\
(0.003) \\
\end{array}$ & $\begin{array}{l}0.000 \\
(0.003) \\
\end{array}$ \\
\hline Ind & $\begin{array}{l}0.007^{*} \\
(0.004)\end{array}$ & $\begin{array}{l}0.005 \\
(0.003)\end{array}$ & $\begin{array}{l}0.007^{*} \\
(0.004)\end{array}$ & $\begin{array}{l}0.007^{*} \\
(0.003)\end{array}$ & $\begin{array}{l}0.005 \\
(0.003) \\
\end{array}$ \\
\hline Scale & $\begin{array}{l}-0.004 \\
(0.01) \\
\end{array}$ & $\begin{array}{l}-0.008 \\
(0.01) \\
\end{array}$ & $\begin{array}{l}-0.004 \\
(0.010) \\
\end{array}$ & $\begin{array}{l}-0.010 \\
(0.010) \\
\end{array}$ & $\begin{array}{l}-0.013 \\
(0.010) \\
\end{array}$ \\
\hline Ethos & & $\begin{array}{l}0.069^{* \star *} \\
(0.022)\end{array}$ & & & $\begin{array}{l}0.060^{* * *} \\
(0.023)\end{array}$ \\
\hline Pathos & & & $\begin{array}{l}0.030 \\
(0.083)\end{array}$ & & $\begin{array}{l}0.005 \\
(0.079)\end{array}$ \\
\hline Logos & & & & $\begin{array}{l}0.069^{\star *} \\
(0.026)\end{array}$ & $\begin{array}{l}0.056^{\star *} \\
(0.026)\end{array}$ \\
\hline F-value & 1.510 & 2.480 & 1.340 & 2.160 & 2.500 \\
\hline $\mathrm{R}^{2}$ & 0.100 & 0.171 & 0.101 & 0.153 & 0.206 \\
\hline
\end{tabular}


$\mathrm{H} 3$ proposes that the CEO's use of logos rhetoric will positively affect the internationalization process of firms. According to Model 5 of Table 2, the coefficient of logos is 0.056 , and the $p$-value is 0.035 , which indicates that logos has a significant impact on the internationalization process of firms at a significance level of 0.05 . Therefore, compared with firms that do not use logos rhetoric, firms that use logos will prove superior in the process of internationalization.

In summary, of the three rhetorical strategies used by CEOs, ethos and logos have a significant positive impact on the internationalization process of the firm, which fully proves the reliability of the research results

\section{Discussion}

Based on upper echelons theory, our research explores how CEOs use rhetorical strategies to persuade employees to participate in the internationalization of a firm and achieve forward results. Overall, the empirical results are in line with our expectations. The data shows that the impact of ethos and logos on the internationalization process of firms is positive and significant, while the impact of pathos is not significant.

Ethos can significantly influence the internationalization process of a firm. CEOs communicate by the rhetoric of Ethos to elaborate the internationalization performance the firm has achieved. These accomplishments symbolize the credit of the firm's international strength and CEO's international strategy, dispel employees' doubts about expanding the firm's overseas business, and form a strong bond of trust among stakeholders. As a result, ethos motivates employees to engage in the subsequent internationalization work, promoting the inter-nationalization process of the firm.

Pathos does not have a significant impact on the internationalization of firms. First, from the selected sample, very few CEOs use pathos rhetoric in their annual reports. The text of the annual report of the firm is mainly based on information disclosure. The text style of the annual report is objective and rational, while the rhetorical strategy of pathos is emotional and passionate, probably conflicting with the writing style of annual reports. In addition, compared with objective and direct data, the driving role of emotional communication skills is more euphemistic and implicit, and it is difficult to mobilize unconscious behavioural feedback through emotional means.

Logos has a significant impact on the internationalization of firms. Logos affects behaviour by influencing the audience's cognition. Resorting to reason aims to analyse the cause and effect of the persuader's argument. Logos motivates employees to think about the attributes and benefits of international activities, making employees gradually understand and agree with the CEO's proposal. Only after deeply understanding the necessity and significance of the internationalization strategy can employees devote themselves to the practice of inter-nationalization.

After analysis and discussion of this research, we've found the CEO rhetoric strategy affects the internationalization process of the firm by motivating stakeholders to participate in it and, finally, improves the firm's internationalization. This research analyses the use of language in the annual report of the firm from a micro-level. Deng (2012) suggested that future research on the internationalization of Chinese firms should be based on upper echelons theory to further explore the internal mechanism of top management team's influence on firm performance. CEO rhetoric technique, which can be seen as an aspect of CEO communicative skills (Den Hartog \& Verburg, 1997), is closely related with upper echelons theory in terms of factors impacting on firm performance and strategic decisions (Anwar, M., Shah Syed Zulfiqar, A., \& Khan Sher, Z., 2018). Therefore, this study attempts to analyse the effect of CEO rhetoric strategies on firms' international performance from the perspective of CEO communication.

\subsection{Theoretical contribution}

We provide several theoretical contributions. Firstly, by extending our understanding of the hypothesized relationship between CEO rhetorical strategy and firm internationalization, we contribute to upper echelons theory that CEOs rhetorical strategies exert effects on firm strategy and performance. Most previous studies based on upper echelon theories started from personal characteristics of CEOs, such as CEOs' age, gender, tenure, education background and personality (Faccio, M., Marchica, M.-T., \& Mura, R., 2016; Hambrick \& Mason, 1984; Jing, G., Hao, C., \& Xian, Z., 2013; Malmendier \& Tate, 2005; Orens \& Reheul, 2013) to investigate how the static 
personal features affect corporate strategic implementation and performance. However, just as Carpenter, Geletkanycz and Sanders (2004) posited, while some scholars have already focused on CEO behaviours such as experience, there are still other behaviours or activities that have been overlooked. Thus, behavioural processes of CEOs have received great attention since it could deepen our understanding of multiple paths of how firms are impacted. In this study, we introduce a relatively new $\mathrm{CEO}$ behaviour-related variable, the Aristotle rhetorical technique of CEOs, and found empirical support of the hypothesized relationship between CEO rhetoric strategies and firm internationalization, which clearly evidenced the tremendous impact of upper echelon theory. Secondly, rhetorical techniques, which can be seen as a tool of CEO communication (Coulson-Thomas, 1992), play a crucial role in strategy implementation. Scholars have already found the impact of CEO communication on the implementation of corporate social responsibility strategy (Liu et al., 2019). Based on the perspective of CEO communication skills, we have demonstrated that two of the rhetoric techniques are positively associated with the firms' internationalization in practice. Thus, CEOs' communicative rhetoric tools are capable of shaping and influencing the strategy of internationalization as well, which further complements the view that CEO rhetorical techniques influence strategic implementation (Den Hartog \& Verburg, 1997).

\subsection{Managerial implications}

This study also offers implications for CEOs. It highlights the importance of CEO skilful communication and suggest that rhetorical strategy is powerful in persuading stakeholders. Since employees' understanding and cooperation of the firm's strategy is essential to guarantee the strategic implementation (Foreman \& Argenti, 2005), the institutionalization of $\mathrm{CEO}$ rhetorical communication could be a trend in firms in international level. From this point of view, CEOs should strive to establish a sound process to communicate rhetorically with both internal and external stakeholders through viable media channels now that stakeholders gather information from the mass media or social media (Zerfass, A., Verčič, D., \& Wiesenberg, M., 2016).

\subsection{Limitations and future research}

The study has a few limitations that invite future research. First, the recognition of rhetorical techniques is by means of manual text analysis which inefficiently consumes time and labour. Nowadays, several mutual software can be taken advantage of for content analysis, such as $\mathrm{R}$ Language, Python, etc. Second, the sample only contains listed Chinese manufacturing firms without private firms or those operate in other industries. It is suggested that future research broaden the sample scope to investigate further the influence of rhetorical strategy in different contexts.

\section{Conclusion}

Despite its caveats, this paper connects the CEO rhetorical strategy with firm inter-nationalization performance. It theorizes and tests the relationship between CEO communication techniques and international strategic implementation. This effort will hopefully deepen our understanding of the antecedents of firm internationalization strategy and the functions of CEO persuasive communication. Our study motivates future research to exploit the rich and complicated reality of firm strategy.sm

\section{References}

Aliber, R. Z. (1970). A theory of foreign direct investment. The International Corporation, 17-34.

Anwar, M., Shah Syed Zulfiqar, A., \& Khan Sher, Z. (2018). The role of personality in SMEs internationalization: empirical evidence. Review of International Business and Strategy, 28(2), 258-282. https://doi.org/10.1108/RIBS-12-2017-0113

Aveling, F., \& Hargreaves, H. (1921). Suggestibility with and without prestige in children. British Journal of Psychology, 12(1), 53-75. https://doi.org/10.1111/j.2044-8295.1921.tb00038.x

Awamleh, R., \& Gardner, W. L. (1999). Perceptions of leader charisma and effectiveness: the effects of vision content, delivery, and organizational performance. The Leadership Quarterly, 10(3), 345-373. https://doi.org/10.1177/0893318903251324

Bagozzi, R. P., Gopinath, M., \& Nyer, P. U. (1999). The role of emotions in marketing. Journal of the Academy of Marketing Science, 27(2), 184-206. https://doi.org/10.1177/0092070399272005

Bangara, A., Freeman, S., \& Schroder, W. (2012). Legitimacy and accelerated internationalisation: an Indian perspective. Journal of World Business, 47(4), 623-634. https://doi.org/10.1016/j.jwb.2011.09.002

Bartlett, C. A., \& Ghoshal, S. (2002). Managing across borders: the transnational solution. Harvard Business Press. 
Bartov, E., Bodnar, G. M., \& Kaul, A. (1996). Exchange rate variability and the riskiness of U.S. multinational firms: evidence from the breakdown of the Bretton Woods system. Journal of Financial Economics, 42(1), 105132.

https://doi.org/https://doi.org/10.1016/0304405X(95)00873-D

Beamish, P. W., Morrison, A. J., \& Rosenzweig, P. M. (1997). International management: Text and Cases. McGraw-Hill/Irwin.

Beckman, C. M., \& Burton, M. D. (2008). Founding the future: path dependence in the evolution of top management teams from founding to IPO. Organization Science, 19(1), 3-24. https://doi.org/10.1287/orsc.1070.0311

Bendisch, F., Larsen, G., \& Trueman, M. (2013). Fame and fortune: a conceptual model of CEO brands. European Journal of Marketing, 47(3/4), 596-614. https://doi.org/10.1108/03090561311297472

Berson, Y., Shamir, B., Avolio, B. J., \& Popper, M. (2001). The relationship between vision strength, leadership style, and context. The Leadership Quarterly, 12(1), 5373. https://doi.org/10.1016/s1048-9843(01)00064-9

Bilkey, W. J., \& Tesar, G. (1977). The export behavior of smaller-sized wisconsin manufacturing firms. Journal of International Business Studies, 8(1), 93-98. https://doi.org/10.1057/palgrave.jibs.8490783

Braet, A. C. (1992). Ethos, pathos and logos in Aristotle's Rhetoric: a re-examination. Argumentation, 6(3), 307320. https://doi.org/10.1007/bf00154696

Brown, A. D., Ainsworth, S., \& Grant, D. (2012). The rhetoric of institutional change. Organization Studies, 33(3), 297-321. https://doi.org/10.1177/0170840611435598

Burtt, H. E., \& Falkenberg, D. R. (1941, 1941/11/01). The influence of majority and expert opinion on religious attitudes. The Journal of Social Psychology, 14(2), 269278. https://doi.org/10.1080/00224545.1941.9918769

Callahan, S. (1988). The role of emotion in ethical decisionmaking. Hastings Center Report, 18(3), 9-14. https://doi.org/10.2307/3562196

Carpenter, M. A., Geletkanycz, M. A., \& Sanders, W. G. (2004). Upper echelons research revisited: antecedents, elements, and consequences of top management team composition. Journal of Management, 30(6), 749-778. https://doi.org/10.1016/j.jm.2004.06.001

Caza, A., Barker, B. A., \& Cameron, K. S. (2004). Ethics and ethos: the buffering and amplifying effects of ethical behavior and virtuousness. Journal of Business Ethics, 52(2), 169-178. https://doi.org/10.1023/b:busi.0000035909.05560.0e

Chance, E. W. (1992). Visionary leadership in schools: successful strategies for developing and implementing an educational vision, Charles C. Thomas Pub Ltd.

Cooper, L. (1935). The rhetoric of Aristotle. Quarterly Journal of Speech, 21(1), 10-19. https://doi.org/10.1080/00335633509380070

Cope, E. M. (1877). The rhetoric of Aristotle: With a commentary (Vol. 2). University Press.
Coulson-Thomas, C. (1992). Strategic vision or strategic con?: Rhetoric or reality? Long range planning, 25(1), 81-89.

https://doi.org/10.1016/0024-6301(92)90313-q

Den Hartog, D. N., \& Verburg, R. M. (1997). Charisma and rhetoric: communicative techniques of international business leaders. The Leadership Quarterly, 8(4), 355391.

https://doi.org/10.1016/S1048-9843(97)90020-5

Den Hartog, D. N., \& Verburg, R. M. (1997). Charisma and rhetoric: Communicative techniques of international business leaders. The Leadership Quarterly, 8(4), 355391.

https://doi.org/10.1016/S1048-9843(97)90020-5

Deng, P. (2012). The internationalization of Chinese firms: a critical review and future research. International Journal of Management Reviews, 14(4), 408-427. https://doi.org/10.1111/j.1468-2370.2011.00323.x

Dunning, J. H. (1993). Internationalizing Porter's diamond. MIR: Management International Review, 33, 7-15. http://www.jstor.org/stable/40228187

Faccio, M., Marchica, M.-T., \& Mura, R. (2016). CEO gender, corporate risk-taking, and the efficiency of capital allocation. Journal of Corporate Finance, 39, 193-209. https://doi.org/10.1016/j.jcorpfin.2016.02.008

Fanelli, A., \& Misangyi, V. F. (2006). Bringing out charisma: CEO charisma and external stakeholders. Academy of Management Review, 31(4), 1049-1061. https://doi.org/10.5465/amr.2006.22528170

Foreman, J., \& Argenti, P. A. (2005). How corporate communication influences strategy implementation, reputation and the corporate brand: an exploratory qualitative study. Corporate Reputation Review, 8(3), 245-264. https://doi.org/10.1057/palgrave.crr.1540253

Gentile-Lüdecke, S., Halaszovich, T., \& Lundan, S. (2019). What role does CEO vision play in the internationalization process of firms? Evidence from the banking sector in Africa. Thunderbird International Business Review, 61(1), 13-27. https://doi.org/10.1002/tie.21958

Gerson, L. P. (1999). Aristotle: Politics, rhetoric and aesthetics (Vol. 4). Taylor \& Francis.

Goleman, D. (1998). The emotional intelligence of leaders. Leader to Leader, 1998(10), 20-26. https://doi.org/10.1002/ttl.40619981008

Grafström, M., \& Falkman Lena, L. (2017). Everyday narratives: CEO rhetoric on Twitter. Journal of Organizational Change Management, 30(3), 312-322. https://doi.org/10.1108/JOCM-10-2016-0197

Haidt, J. (2007). The new synthesis in moral psychology. Science, 316(5827), 998-1002. https://doi.org/10.1126/science.1137651

Hallahan, K., Holtzhausen, D., van Ruler, B., Verčič, D., \& Sriramesh, K. (2007). Defining strategic communication. International Journal of Strategic Communication, 1(1), 3-35. https://doi.org/10.1080/15531180701285244

Halloran, S. M. (1982). Aristotle's concept of ethos, or if not his somebody else's. Rhetoric Review, 1(1), 58-63. https://doi.org/10.1080/07350198209359037 
Hambrick, D. C., \& Mason, P. A. (1984). Upper echelons: the organization as a reflection of its top managers. Academy of Management Review, 9(2), 193-206. https://doi.org/10.5465/amr.1984.4277628

Harms, L. (1961). Listener comprehension of speakers of three status groups. Language and Speech, 4(2), 109112. https://doi.org/10.1177/002383096100400203

Hatfield, E., Rapson, R. L., \& Le, Y.-C. L. (2011). Emotional contagion and empathy. In J. Decety \& W. Ickes(Eds.), The social neuroscience of empathy(pp.19-30). MIT Press. https://doi.org/10.7551/mitpress/9780262012973.003.0 $\underline{003}$

Haynes, K. T., \& Hillman, A. (2010). The effect of board capital and CEO power on strategic change. Strategic Management Journal, 31(11), 1145-1163. https://doi.org/10.1002/smj.859

Herrmann, P., \& Datta, D. K. (2005). Relationships between top management team characteristics and international diversification: an empirical investigation. British Journal of Management, 16(1), 69-78. https://doi.org/10.1111/j.1467-8551.2005.00429.x

Hitt, M. A., Hoskisson, R. E., \& Ireland, R. D. (1994). a midrange theory of the interactive effects of international and product diversification on innovation and performance. Journal of management, 20(2), 297-326. https://doi.org/10.1177/014920639402000203

Holt, R., \& Macpherson, A. (2010). Sensemaking, rhetoric and the socially competent entrepreneur. International Small Business Journal, 28(1), 20-42. https://doi.org/10.1177/0266242609350822

Huang, Y., \& Rose, K. (2018). You, our shareholders: metadiscourse in CEO letters from Chinese and Western banks. Text \& Talk, 38(2), 167-190. https://doi.org/10.1515/text-2017-0041

Humphrey, R. H. (2002). The many faces of emotional leadership. The Leadership Quarterly, 13(5), 493-504. https://doi.org/10.1016/s1048-9843(02)00140-6

Hymer, S. H. (1976). The international operations of national firms: $A$ study of foreign direct investment. Cambridge, MA: MIT Press.

Jaw, Y.-L., \& Lin, W.-T. (2009). Corporate elite characteristics and firm's internationalization: CEO-level and TMT-level roles. The International Journal of Human Resource Management, 20(1), 220-233. https://doi.org/10.1080/09585190802528797

Jing, G., Hao, C., \& Xian, Z. (2013). Influence of psychological and emotional factors on the venture enterprise value and the investment decision-making. Procedia Computer Science, 17, 919-929. https://doi.org/10.1016/j.procs.2013.05.117

Jones, M. V., \& Coviello, N. E. (2005). Internationalisation: conceptualising an entrepreneurial process of behaviour in time. Journal of International Business Studies, 36(3), 284-303. https://doi.org/10.1057/palgrave.jibs. 8400138

Kallendorf, C., \& Kallendorf, C. (1985). The figures of speech, ethos, and Aristotle: notes toward a rhetoric of business communication. The Journal of Business Communication, 22(1), 35-50. https://doi.org/10.1177/002194368502200102
Keller-Bacher, J., \& Zerfass, A. (2019). How strategic communication facilitates the internationalization of firms: a situational framework. Big Ideas in Public Relations Research and Practice (4, pp.1-24). Emerald Publishing Limited. https://doi.org/10.1108/S2398-391420190000004002

Kennedy, G. A. (2007). Aristotle on Rhetoric: A Theory of Civic Discourse: Translated with Introduction, Notes and Appendices. Oxford: Oxford University Press.

Kim, W. C., Hwang, P., \& Burgers, W. P. (1993). Multinationals' diversification and the risk-return tradeoff. Strategic Management Journal, 14(4), 275-286. https://doi.org/10.1002/smj.4250140404

Konstan, D. (2006). The Emotions of the Ancient Greeks: Studies in Aristotle and Classical Literature (Vol. 5). University of Toronto Press. https://doi.org/10.3138/9781442674370

Larwood, L., Falbe, C. M., Kriger, M. P., \& Miesing, P. (1995). Structure and meaning of organizational vision. Academy of Management Journal, 38(3), 740-769. https://doi.org/10.5465/256744

Lieberman, M. D. (2007). Social cognitive neuroscience: a review of core processes. Annual Review of Psychology, 58, 259-289. https://doi.org/10.1146/annurev.psych.58.110405.08565 4

Liu, C., Chen, S., \& Shao, Q. (2019). Do CEO rhetorical strategies affect corporate social performance? Evidence from China. Sustainability, 11(18), 4907. https://doi.org/10.3390/su11184907

Liu, X. H., GE, Y. H., \& Wang, Q. (2014). The effects of TMT interaction on enterprise performance from the perspective of enterprise culture. African Journal of Business Management, 8(4), 137-145. https://doi.org/10.5897/AJBM2013.7246

Malmendier, U., \& Tate, G. (2005). CEO overconfidence and corporate investment. The Journal of Finance, 60(6), 2661-2700.p https://doi.org/10.1111/j.1540-6261.2005.00813.x

McKiernan, P. (1992). Strategies of growth: Maturity, recovery, and internationalization. Routledge.

Men, L. R. (2012, 2012/03/01/). CEO credibility, perceived organizational reputation, and employee engagement. Public Relations Review, 38(1), 171-173. https://doi.org/https://doi.org/10.1016/j.pubrev.2011.12. $\underline{011}$

Orens, R., \& Reheul, A.-M. (2013). Do CEO demographics explain cash holdings in SMEs? European Management Journal, 31(6), 549-563. https://doi.org/10.1016/j.emj.2013.01.003

Rosenthal, P. I. (1966). The concept of ethos and the structure of persuasion. Communications Monographs, 33(2), 114-126. https://doi.org/10.1080/03637756609375487

Sandy Edward Green, J. (2004). A rhetorical theory of diffusion. Academy of Management Review, 29(4), 653669. https://doi.org/10.5465/amr.2004.14497653

Scherer, A. G., \& Palazzo, G. (2007). Toward a political conception of corporate responsibility: business and society seen from a Habermasian perspective. Academy of Management Review, 32(4), 1096-1120. https://doi.org/10.5465/amr.2007.26585837 
Schwarz, N. (2000). Emotion, cognition, and decision making. Cognition \& Emotion, 14(4), 433-440. https://doi.org/10.1080/026999300402745

Shamir, B., Arthur, M. B., \& House, R. J. (1994). The rhetoric of charismatic leadership: a theoretical extension, a case study, and implications for research. The Leadership Quarterly, 5(1), 25-42. https://doi.org/https://doi.org/10.1016/10489843(94)90004-3

Sohn, Y. Y., Weaver Lariscy, R., \& Tinkham, S. F. (2009). The impact of CEO reputation: negative news and economic decisions. International Journal of Strategic Communication, 3(1), 1-18. https://doi.org/10.1080/15531180802606596

Stalnaker, R. (2002). Common ground. Linguistics and philosophy, 25(5/6), 701-721. https://doi.org/10.1023/A:1020867916902

Suchman, M. C. (1995). Managing legitimacy: strategic and institutional approaches. Academy of Management Review, 20(3), 571-610. https://doi.org/10.5465/amr.1995.9508080331

Tallman, S., \& Li, J. (1996). Effects of international diversity and product diversity on the performance of multinational firms. Academy of Management Journal, 39(1), 179-196 https://doi.org/10.5465/256635

Tihanyi, L., Ellstrand, A. E., Daily, C. M., \& Dalton, D. R. (2000). Composition of the top management team and firm international diversification. Journal of management, 26(6), 1157-1177. https://doi.org/10.1177/014920630002600605

Verčič, D., \& Grunig, J. E. (2000). The origins of public relations theory in economics and strategic management. In D. Moss, D. Vercic, G.Warnaby (Eds.), Perspectives on public relations research(pp.9-58), Routledge. https://doi.org/10.4324/9780203192924-8

Vernon, R. (1966). International investment and international trade in the product cycle. Quarterly Journal of Economics, 80(2), 190-207. https://doi.org/10.2307/1880689

Waddell, C. (1990). The role of pathos in the decisionmaking process: a study in the rhetoric of science policy. Quarterly Journal of Speech, 76(4), 381-400. https://doi.org/10.1080/00335639009383932

\section{$\triangle$ Correspondence}

\section{Peien Chen}

Eli Broad College of Business, Michigan State University East Lansing, MI 48824, USA

E-mail: chenpeie@msu.edu
Wæraas, A. (2010). Communicating identity:the use of core value statements in regulative institutions. Administration \& Society, 42(5), 526-549. https://doi.org/10.1177/0095399710377435

Wang, G., \& Seibert, S. E. (2015). The impact of leader emotion display frequency on follower performance: Leader surface acting and mean emotion display as boundary conditions. The Leadership Quarterly, 26(4), 577-593. https://doi.org/10.1016/j.leaqua.2015.05.007

Wells, L. T. (1968). A product life cycle for international trade? Journal of Marketing, 32(3), 1-6. https://doi.org/10.1177/002224296803200301

Wind, Y., Douglas, S. P., \& Perlmutter, H. V. (1973). Guidelines for developing international marketing strategies. Journal of Marketing, 37(2), 14-23. https://doi.org/10.1177/002224297303700205

Wolf, B. M. (1977). Industrial diversification and internationalization: some empirical evidence. The Journal of Industrial Economics, 26(2), 177-191. https://doi.org/10.2307/2097937

Yoeli, R., \& Berkovich, I. (2010). From personal ethos to organizational vision: narratives of visionary educational leaders. Journal of Educational Administration, 48(4), 451-467. https://doi.org/10.1108/09578231011054716

Zahra, S. A., Neubaum, D. O., \& El-Hagrassey, G. M. (2002). Competitive analysis and new venture performance: understanding the impact of strategic uncertainty and venture origin. Entrepreneurship Theory and Practice, 27(1), 1-28.

https://doi.org/10.1111/1540-8520.t01-2-00001

Zerfass, A., Verčič, D., \& Wiesenberg, M. (2016). Managing CEO communication and positioning: A cross-national study among corporate communication leaders. Journal of Communication Management, 20(1), 37-55. https://doi.org/10.1108/JCOM-11-2014-0066

Zimmerman, M. A., \& Zeitz, G. J. (2002). Beyond survival: achieving new venture growth by building legitimacy. Academy of Management Review, 27(3), 414-431. https://doi.org/10.5465/amr.2002.7389921 